\title{
PENERAPAN MODEL PEMBELAJARAN CONTEXTUAL TEACHING AND LEARNING (CTL) PADA MATERI KINETIKA KIMIA
}

\author{
Ayu Rahmi \\ Fakultas Keguruan dan Ilmu Pendidikan, Universitas Malikussaleh \\ Email: aiu.rahmi@gmail.com
}

\begin{abstract}
Abstrak: Penelitian yang berjudul "Penerapan Model Pembelajaran Contextual Teaching and Learning (CTL) pada Materi Kinetika Kimia" ini mengangkat masalah apakah dengan penerapan model pembelajaran CTL dapat meningkatkan aktivitas dan hasil belajar mahasiswa pada materi kinetika kimia. Penelitian dilakukan di FKIP Universitas Malikussaleh. Penelitian ini dilaksanakan pada 5-28 Febuari 2018. Subjek dalam penelitian ini adalah mahasiswa Prodi Pendidikan Kimia semester II tahun ajaran 2017/2018 yang berjumlah 30 orang, terdiri dari 4 laki-laki dan 18 perempuan. Untuk mengetahui aktivitas mahasiswa, dilakukan observasi dengan menggunakan lembar pengamatan. Dari hasil pengamatan diketahui aktivitas mahasiswa mengalami perubahan menjadi lebih baik dari siklus I ke siklus II. Disamping itu, untuk mengetahui peningkatan hasil belajar mahasiswa dengan menggunakan model CTL, diberikan tes tulis dan diperoleh bahwa hasil belajar mahasiswa mengalami peningkatan. Pada siklus I persentase hasil belajar pada pertemuan pertama sebesar $56,67 \%$ menjadi $70,00 \%$ pada pertemuan kedua. Setelah siklus II dilaksanakan, persentase hasil belajar lebih meningkat dari76,00\% menjadi 91,67\%. Berdasarkan hasil penelitian dapat disimpulkan bahwa penerapan model pembelajaran CTL dapat meningkatkan aktivitas dan hasil belajar mahasiswa pada materi kinetika kimia.
\end{abstract}

\section{Kata Kunci: model pembelajran, CTL, hasil belajar}

\section{APPLICATION OF CONTEXTUAL TEACHING AND LEARNING (CTL) LEARNING MODELS IN CHEMICAL KINETICS MATERIALS}

Abstract: The study entitled "Application of Contextual Teaching and Learning (CTL) Learning Models in Chemical Kinetics Materials" raised the issue of whether the application of CTL learning models can increase student activity and learning outcomes on chemical kinetics. The research was conducted at FKIP University of Malikussaleh. This research was conducted on February 5-28 2018. Subjects in this study were students of Chemistry Education Study Program for the second semester of 2017/2018 academic year totaling 30 people, consisting of $4 \mathrm{men}$ and 18 women. To find out the activities of students, observations were made using an observation sheet. From the results of the observation, it is known that the student's activity changes for the better from cycle I to cycle II. In addition, to find out the improvement of student learning outcomes by using the CTL model, a written test was given and it was found that student learning outcomes had increased. In cycle I the percentage of learning outcomes at the first meeting was $56.67 \%$ to $70.00 \%$ at the second meeting. After the second cycle was implemented, the percentage of learning outcomes increased from $76.00 \%$ to $91.67 \%$. Based on the results of the study it can be concluded that the application of the CTL learning model can increase student activity and learning outcomes on chemical kinetics.

Keywords: learning model, CTL, learning outcomes 


\section{PENDAHULUAN}

Kimia merupakan cabang ilmu pengetahuan alam yang mempelajari tentang susunan, struktur, sifat, dan perubahan materi. Disamping itu, kimia juga berhubungan dengan berbagai mata pelajaran IPA, seperti fisika dan biologi. Kimia itu sendiri berkenaan dengan ide-ide/konsep-konsep yang abstrak yang tersusun secara hirarkhi dan penalaran deduktif (Dwipurwani, dkk, 2012). Hal ini menyebabkan timbulnya opini dikalangan mahasiswa bahwa kimia merupakan pelajaran yang tidak mudah untuk dimengerti karena sebagian besar materinya terlalu banyak berhubungan dengan materi yang terdapat pada pelajaran lainnya. Seperti pada materi kinetika kimia, mahasiswa seringkali kurang tepat dalam menjelaskan pengertian kinetika kimia. Mereka kesulitan untuk membedakan antara kinetika kimia dengan termodinamika kimia. Begitu pula dalam memaparkan faktor-faktor yang mempengaruhi laju reaksi. Apabila mahasiswa tidak terlibat aktif dalam proses pembelajaran, tentu hasil belajar yang diperoleh kurang memuaskan. Disamping itu, penyampaian materi oleh dosen juga dapat mempengaruhi minat mahasiswa untuk belajar.

Pelaksanaan pembelajaran di kampus harus diatur sedemikian rupa sehingga dapat menciptakan suanana belajar yang menarik dan menyenangkan. Untuk itu, mengutamakan mahasiswa dalam proses pembelajaran merupakan cara untuk dapat menarik minat mereka terhadap materi yang sedang dipelajari sehingga menjadi lebih aktif dan kreatif. Untuk membantu dosen menciptakan suasana belajar yang menyenangkan tersebut, dapat digunakan suatu model pembelajaran. Hal ini akan menguntungkan bagi mahasiswa karena selain lebih aktif dan kreatif, motivasi mereka juga meningkat untuk belajar sehingga diperoleh hasil belajar yang memuaskan.

Belakangan ini, model pembelajaran untuk mata pelajaran kimia hanya diterapkan oleh beberapa dosen saja. Hal ini diketahui dari hasil studi pendahuluan berupa wawancara dengan beberapa orang dosen dan mahasiswa. Hasil studi pendahuluan tersebut menunjukkan bahwa penggunaan model pembelajaran perlu dilakukan agar dapat meningkatkan aktivitas mahasiswa yang pada akhirnya juga akan berdampak pada hasil belajar mereka.

Untuk mengatasi permasalahan yang dikemukakan di atas, model Contextual Teaching and Learning (CTL) merupakan model pembelajaran yang sesuai untuk mengatasinya. CTL adalah suatu model yang menekankan kepada proses keterlibatan mahasiswa secara utuh dalam kegiatan pembelajaran. Model ini juga mendorong mereka untuk membuat hubungan antara subjek-subjek materi pembelajaran dan pengetahuan yang dimilikinya dengan penerapannya dalam kehidupan sehari-hari (Nurhadi, 2002).

Kelebihan model pembelajaran CTL dibandingkan dengan model pembelajaran lainnya yaitu model ini merupakan model pembelajaran bermakna, artinya mahasiswa secara aktif melakukan sendiri kegiatan yang berhubungan dengan materi yang ada sehingga mereka dapat memahami materi dengan mudah. Mahasiswa juga dapat berpikir kritis dan kreatif dalam mengumpulkan data untuk memecahkan masalah. Disamping itu, pembelajaran lebih produktif dan mampu menumbuhkan penguatan konsep kepada mahasiswa.

Berdasarkan latar belakang di atas, penulis tertarik untuk menerapkan model pembelajaran Contextual Teaching and Learning (CTL) pada materi kinetika kimia di Program Studi Pendidikan Kimia Fakultas Keguruan dan Ilmu Pendidikan Universitas Malikussaleh. Penerapan model ini diharapkan dapat meningkatkan aktivitas dan pemahaman mahasiswa terhadap materi yang dipelajari sehingga hasil belajarnya juga meningkat. Tujuan penerapan model pembelajaran CTL adalah untuk mengetahui jawaban atas permasalahan yang akan diungkapkan, yaitu apakah dengan menerapkan model pembelajaran CTL dapat meningkatkan aktivitas dan hasil belajar mahasiswa pada materi kinetika kimia? 


\section{METODE}

\section{Setting Penelitian}

Penelitian ini dilaksanakan pada Fakultas Keguruan dan Ilmu Pendidikan, Universitas Malikussaleh. Subjek dalam penelitian ini adalah mahasiswa Program Studi Kimia semester II (dua) tahun ajaran 2017/2018 yang berjumlah 30 orang, terdiri atas 4 orang laki-laki dan 26 perempuan. Penelitian ini dilaksanakan pada tanggal 5 Februri hingga 28 Februari 2018. Penelitian ini merupakan penelitian tindakan kelas yang dilaksanakan dalam dua siklus.

\section{Teknik Pengumpulan Data}

Pengumpulan data terdiri atas dua tahap, yaitu tahap perencanaan dan persiapan, dan tahap pelaksanaan. Pada tahap perencanaan dan persiapan, yang perlu dilakukan adalah menentukan jumlah siklus pertemuan, kelas yang akan digunakan, materi yang akan dibahas, membuat rencana pembelajaran, dan menyusun evaluasi dan instrumen. Instrumen yang digunakan adalah 1) tes tertulis; berupa soal yang berisi pertanyaan tentang materi kinetika kimia, 2) lembar observasi; yaitu lembar observasi untuk aktivitas mahasiswa selama proses belajar mengajar.

Pada pertemuan sebelum siklus pertama, dilakukan tes awal (pre-test) terhadap mahasiswa untuk menguji kemampuan mereka tentang materi kinetika kimia. Pelaksanaan kegiatan belajar mengajar (KBM) untuk tiap kali pertemuan mengikuti siklus rancangan penelitian tindakan kelas, yaitu rencana-tindakan-observasi-refleksi.

Pada tahap perencanaan dan persiapan, peneliti menyusun rancangan pembelajaran untuk siklus I. Selain itu, peneliti juga mempersiapkan perangkat pembelajaran lain yang dibutuhkan untuk pertemuan dalam siklus ini. Selanjutnya, dosen sebagai peneliti melakukan tindakan, yaitu membagi mahasiswa menjadi beberapa kelompok belajar serta melakukan KBM sesuai dengan rancangan pembelajaran yang akan digunakan pada siklus I. Selama mahasiswa bekerja, peneliti melakukan pengawasan kepada setiap kelompok untuk mengetahui aktivitas mahasiswa dalam belajar kelompok. Setelah semua proses pembelajaran dalam siklus I selesai dilaksanakan, mahasiswa diuji dengan post-test yang bertujuan untuk mengetahui apakah ada peningkatan hasil belajar mahasiswa setelah kegiatan belajar mengajar dengan menggunakan model pembelajaran CTL.

Pada tahap pelaksanaan, dilakukan pengamatan dan observasi oleh dosen terhadap aktivitas mahasiswa. Setelah proses pembelajaran berakhir, dosen melakukan refleksi terhadap pelaksanaan proses pembelajaran berdasarkan rencana pembelajaran. Hasil refleksi dijadikan pedoman dalam revisi kelemahan pada siklus I dan menyusun rencana pertemuan untuk siklus II. Berdasarkan hasil refleksi atau masukan pada siklus pertama, peneliti menyiapkan rancangan pembelajaran untuk siklus ke-II yang disesuaikan dengan hasil pre-test.

Dari uraian di atas, maka inti dari penelitian ini adalah adanya tindakan untuk memperbaiki proses pelaksanaan kegiatan belajar mengajar dengan meningkatkan aktivitas mahasiswa dalam proses pembelajaran sehingga mereka akan memperoleh hasil belajar yang memuaskan. Langkah-langkah pelaksanaan tindakan meliputi keempat komponen yang telah disebutkan di atas dan berlangsung secara siklus sehingga tercapai tujuan yang diinginkan dengan tindakan yang paling efektif.

\section{Teknik Pengolahan Data}

Teknik pengolahan data yang akan digunakan dalam penelitian ini yaitu menggunakan metode statistik deskriptif persentase dengan menggunakan langkahlangkah sebagai berikut:

a. Untuk mengetahui hasil belajar mahasiswa dengan menggunakan model pembelajaran CTL pada materi kinetika kimia, digunakan statistik deskriptif persentase dengan rumus: 
$P=\frac{F}{N} \times 100 \%$

Keterangan:

Persentase yang dicari dilambangkan P. Untuk tingkat ketuntasan individual, $\mathrm{F}$ adalah frekuensi soal yang dijawab benar dan $\mathrm{N}$ adalah jumlah soal. Sedangkan untuk tingkat ketuntasan klasikal, $\mathrm{F}$ adalah frekuensi mahasiswa yang menjawab benar dan $\mathrm{N}$ adalah jumlah mahasiswa (Soedjiono, 2001).

b. Lembar pengamatan aktivitas mahasiswa dalam kegiatan belajar mengajar

Untuk mengetahui sejauh mana aktivitas mahasiswa dalam kegiatan belajar mengajar dengan menggunakan model pembelajaran CTL, digunakan lembar pengamatan. Pengamatan dilakukan selama kegiatan belajar mengajar berlangsung.

\section{HASIL DAN PEMBAHASAN}

\section{Nilai Pre-Test}

Sebelum proses pembelajaran dimulai, dilakukan pre-test (tes awal) yang bertujuan untuk mengetahui pengetahuan mahasiswa pada materi kinetika kimia sebelum diberikan pembelajaran dengan menggunakan model pembelajaran CTL. Berdasarkan nilai tes tersebut, nilai tertinggi yang diperoleh mahasiswa adalah 35, dan nilai terendah 10 . Nilai yang diperoleh diklasifikasikan ke dalam 3 katagori, yaitu katagori tinggi dengan rentang nilai 80100, katagori sedang dengan rentang nilai $65-79$, dan katagori rendah dengan rentang nilai kurang dari 65 (Purwanto, 2004).

Tabel 1. Distribusi Nilai Pre-Test Mahasiswa pada Materi Kinetika Kimia

\begin{tabular}{|l|c|c|c|}
\hline \multicolumn{1}{|c|}{ Katagori } & Skor & Frekuensi & Persentase (\%) \\
\hline Tinggi & $80-100$ & 0 & 0 \\
\hline Sedang & $65-79$ & 0 & 0 \\
\hline Rendah & $<65$ & 30 & 100 \\
\hline
\end{tabular}

Tabel 1 menunjukkan bahwa katagori nilai yang diperoleh dari hasil pre-test seluruh mahasiswa (100\%) termasuk dalam katagori rendah, yaitu lebih kecil dari 65. Artinya, tidak ada mahasiswa yang tuntas belajar sebelum menggunakan CTL.

Hasil penelitian dan pembahasan diuraikan secara bertahap sesuai dengan pelaksanaannya dalam proses belajar mengajar di kelas. Dalam penelitian ini, pembelajaran dilakukan dalam dua siklus.

\section{Hasil Siklus I}

Pada pertemuan pertama dalam siklus I, nilai rata-rata hasil belajar mahasiswa adalah 51,50 dengan persentase sebesar $56,67 \%$. Hasil belajar yang diperoleh mahasiswa pada pertemuan pertama ini sudah lebih baik dibandingkan dengan nilai tes pre-test, sehingga dapat dikatakan hasil belajar mahasiswa lebih baik setelah diterapkan model pembelajaran CTL.

Pada pertemuan kedua dalam siklus I, nilai rata-rata hasil belajar mahasiswa lebih baik, yaitu 68,50 dengan persentase sebesar 70,00\%. Akan tetapi, hasil tersebut belum mencapai kriteria ketuntasan yang ingin dicapai, yaitu sebesar $85 \%$ dari jumlah seluruh mahasiswa, sehingga diperlukan refleksi terhadap tindakan yang akan dilakukan pada siklus II.

Aktivitas mahasiswa pada siklus I belum dikatakan relevan dengan pembelajaran. Pada siklus ini, mahasiswa belum sepenuhnya terlibat aktif dalam pembelajaran. Mereka belum berani berpendapat atau mengemukakan ide-ide masalah sehari-hari yang pernah dilihat atau dialami mengenai materi kinetika kimia. 


\section{Hasil Siklus II}

Pada pertemuan pertama dalam siklus II, nilai rata-rata hasil belajar mahasiswa sudah lebih baik dibandingkan dengan siklus sebelumnya, yaitu 72,50 dengan persentase sebesar 76,00\%. Pada pertemuan kedua dalam siklus II nilai rata-rata mahasiswa semakin meningkat, yaitu 83,00 dengan persentase keluntasan secara klasikal yaitu 91,67\%. Perolehan ketuntasan secara klasikal pada siklus II baik pada pertemuan pertama maupun pertemuan kedua telah mencapai kriteria ketuntasan klasikal yaitu lebih dari 85\% dari jumlah seluruh mahasiswa.

Untuk aktivitas mahasiswa pada siklus II sudah dapat dikatakan relevan dengan pembelajaran. Pada siklus ini, mahasiswa hampir sepenuhnya terlibat aktif dalam pembelajaran. Mahasiswa sudah mulai berani berpendapat atau mengemukakan ide-ide masalah sehari-hari yang pernah dilihat atau dialami mengenai materi kinetika kimia.

Berdasarkan uraian di atas, penerapan model CTL pada materi kinetika kimia dapat meningkatkan hasil belajar mahasiswa. Hal ini dapat dilihat pada tabel 2.

Tabel 2. Perolehan Hasil Belajar Siklus I dan II

\begin{tabular}{|c|l|c|c|}
\hline \multirow{2}{*}{ Kegiatan } & \multicolumn{2}{c|}{ Perolehan Hasil Belajar } \\
\cline { 2 - 4 } & Pertemuan 1 & Nilai Rata-Rata & \% Ketuntasan \\
\cline { 2 - 4 } Siklus I & Pertemuan 2 & 51,50 & 56,67 \\
\hline \multirow{2}{*}{ Siklus II } & Pertemuan 1 & 68,50 & 70,00 \\
\cline { 2 - 4 } & Pertemuan 2 & 72,50 & 76,00 \\
\hline
\end{tabular}

Hasil pengamatan terhadap aktivitas mahasiswa yang relevan dengan pembelajaran dengan menggunakan model CTL pada materi kinetika kimia dapat dilihat pada tabel 3.

Tabel 3. Hasil Observasi Aktivitas Mahasiswa yang Relevan pada Pembelajaran CTL

\begin{tabular}{|c|l|c|c|c|c|}
\hline \multirow{2}{*}{ No } & \multicolumn{1}{|c|}{ Aspek yang Diamati } & \multicolumn{2}{|c|}{ Siklus I } & \multicolumn{2}{c|}{ Siklus II } \\
\cline { 3 - 6 } & $\begin{array}{c}\text { Pertemuan } \\
1\end{array}$ & $\begin{array}{c}\text { Pertemuan } \\
2\end{array}$ & $\begin{array}{c}\text { Pertemua } \\
\mathrm{n} 1\end{array}$ & $\begin{array}{c}\text { Pertemua } \\
\mathrm{n} 2\end{array}$ \\
\hline 1 & $\begin{array}{l}\text { Keberanian mahasiswa dalam } \\
\text { bertanya dan berpendapat }\end{array}$ & $\begin{array}{c}\text { Sangat } \\
\text { rendah }\end{array}$ & Rendah & tinggi & $\begin{array}{c}\text { Sangat } \\
\text { tinggi }\end{array}$ \\
\hline 2 & $\begin{array}{l}\text { Motivasi mahasiswa dalam } \\
\text { pembelajaran }\end{array}$ & $\begin{array}{l}\text { Sangat } \\
\text { rendah }\end{array}$ & Rendah & Tinggi & $\begin{array}{c}\text { Sangat } \\
\text { tinggi }\end{array}$ \\
\hline 3 & Kerjasama dalam kelompok & Rendah & Rendah & Tinggi & Tinggi \\
\hline 4 & $\begin{array}{l}\text { Interaksi dengan teman dalam } \\
\text { kelompok }\end{array}$ & Rendah & Tinggi & $\begin{array}{c}\text { Sangat } \\
\text { tinggi }\end{array}$ & $\begin{array}{c}\text { Sangat } \\
\text { tinggi }\end{array}$ \\
\hline 5 & $\begin{array}{l}\text { Keberanian mendemonstrasikan } \\
\text { hasil kerja kelompok }\end{array}$ & Rendah & Rendah & Tinggi & Tinggi \\
\hline 6 & $\begin{array}{l}\text { Partisipasi mahasiswa dalam } \\
\text { pembelajaran }\end{array}$ & rendah & Tinggi & $\begin{array}{c}\text { Sangat } \\
\text { tinggi }\end{array}$ & $\begin{array}{c}\text { Sangat } \\
\text { tinggi }\end{array}$ \\
\hline
\end{tabular}

Uraian di atas menunjukkan bahwa penerapan model pembelajaran CTL dapat meningkatkan aktivitas dan hasil belajar mahasiswa dalam materi kinetika kimia. Hal ini disebabkan karena mahasiswa dapat secara aktif terlibat dalam proses pembelajaran. Disamping itu, mereka dapat belajar melalui kerja kelompok, diskusi, saling mengoreksi, dan yang paling penting adalah mahasiswa bisa langsung mengaitkan materi yang sedang dipelajari dengan kehidupan sehari-hari, sehingga hal ini memudahkan bagi mereka untuk dapat dengan mudah memahami materi yang dipelajari tersebut (Nurhadi dan Senduk, 2003). 


\section{PENUTUP}

Adapun kesimpulan dari hasil penelitian ini adalah

1. Penerapan model pembelajaran Contextual Teaching and Learning dapat meningkatkan aktivitas belajar mahasiswa pada materi kinetika kimia.

2. Penerapan model pembelajaran Contextual Teaching and Learning dapat meningkatkan hasil belajar mahasiswa pada materi kinetika kimia.

\section{UCAPAN TERIMA KASIH}

Peneliti mengucapkan terima kasih yang sebesar-besarnya kepada rekan-rekan yang telah membantu dari awal hingga selesainya penelitian ini. Peneliti juga berterima kasih kepada seluruh pihak yang telah memberikan dukungan untuk terlaksananya kegiatan ini.

\section{DAFTAR PUSTAKA}

Dwipurwani, Oki, Maiyanti, Sri Indra, Desiani, Anita dan Suryati, Sari. 2012, Jurnal Penelitian Sains. Vol, 15, No, 1 (A) 15101. hal.47.

Nurhadi. 2002. Pendekatan Kontekstual. Jakarta: Departemen Pendidikan Nasional, Dirjendikdasmen.

Nurhadi dan Senduk. (2003). Kontekstual dan Penerapannya dalam KBK. Malang: Universitas Malang Press.

Purwanto. (2003). Psikologi Pendidikan. Bandung: Remaja Rosdakarya.

Soedjiono, Anas. (2001). Pengantar Statistik Pendidikan. Jakarta: PT. Grafindo Persada. 